\title{
HARMONIZATION OF ASEAN LAWS ON PROTECTION OF MIGRANT WORKERS AGAINST HUMAN TRAFFICKING
}

\author{
Zainal Amin Ayub ${ }^{1}$ \\ Zuryati Mohammed Yusoof ${ }^{2}$ \\ Faculty of Law, University Of North Malaysia, Malaysia \\ ${ }^{1}$ E-mail:z.amin@uum.edu.my \\ ${ }^{2}$ E-mail: zuryati@umm.edu.my
}

\begin{abstract}
The realization of ASEAN Community 2015 opens a hope of a new era for migrant workers amongst its member countries. The hope is on the comprehensive legal protection for migrant workers against injustice as well as trafficking in the ASEAN Communities. This article aims to looks into the legal framework within few ASEAN countries that provides protection for migrant workers against injustice and human trafficking, and the available recourse to justice for them in case they become the victim of human trafficking. Malaysia becomes the case study as lesson learnt. Doctrinal methodology is adopted in this article. It is found that, in regards to protection of migrant workers, despite the establishment of ASEAN Community 2015, the laws on this regard are scattered. A few members of ASEAN Community are reluctant to embed the protection of migrant workers into their national laws. Also, it is found that ASEAN country like Malaysia has the laws at national level to curb human trafficking of migrant workers. However, though the laws seem to be comprehensive, the effectiveness of its implementation and enforcement of the laws are yet to be seen. It is suggested that the laws on protection of migrant workers to be harmonized and standardised between members of ASEAN Community and the cooperation within members of ASEAN should be enhanced at every level.
\end{abstract}

Keywords: ASEAN; migrant workers; human trafficking; illegal immigrants; smuggling migrant

\section{Introduction}

There are always intensive global campaigns seek to demand the protection of refugees' human rights, dignity of migrants, to stop trafficking in persons held at regional, inter-regional and international bodies and governments. The least of the pressure is that countries to recognise, become signatories or ratify international instruments on human rights and implement them at national level. ${ }^{1}$

The south-east Asian countries under the auspicious of Association of Southeast Asian Nations or ASEAN applauds the international commitment for human rights and freedoms as set out in the Vienna Declaration. ${ }^{2}$ The ASEAN member countries also have taken efforts to protect the rights

\footnotetext{
${ }^{1}$ Chavez, J. J. (2007). Social policy in ASEAN: the prospects for integrating migrant labour rights and protection. Global Social Policy, 7(3), 358-378.

${ }_{2}^{2}$ Chalermpalanupap, M. T. (1993). 10 Facts about ASEAN Human Rights Cooperation. World, 14, 25.
} 
and welfare of women, children, and migrant workers. This can be seen when ASEAN member countries also supports the 2000 Palermo Protocol Against Trafficking. It was estimated that $800,000-900,000$ people are trafficked across international borders and held captive in slave-like situations of forced labour or sexual slavery yearly. The 2000 Palermo Protocol against Trafficking i.e. Article 3(a) of the 2000 Protocol to Prevent, Suppress and Punish Trafficking in Person, defines trafficking as "the recruitment, transportation, transfer, harbouring or receipt of persons, by means of the threat or use of force or other forms of coercion, of abduction, of fraud, of deception, of the abuse of power or of a position of vulnerability or of the giving or receiving of payments or benefits to achieve the consent of a person having control over another person, for the purpose of exploitation. Exploitation shall include, at a minimum, the exploitation of the prostitution of others or other forms of sexual exploitation, forced labour or services, slavery or practices similar to slavery, servitude or the removal of organs". 3

However, it is noted that there are lacked of comprehensive legislation among the ASEAN member countries in protecting indigenous peoples, lack of a clear provision

\footnotetext{
${ }^{3}$ Wuiling, C. (2006). Assessing criminal justice and human rights models in the fight against sex trafficking: A case study of the ASEAN region. Essex Human Rights Review, 3(1), 46-63.
}

on the protection of children as well as migrant workers ${ }^{4}$ against human trafficking despite the fact that the crime of human trafficking remains the third most profitable transnational criminal activity, after drug smuggling and illegal trading in firearms. The ASEAN countries are claimed to be inadequately addressing the problem of human trafficking as the laws in the respective countries of ASEAN penalize the traffickers but fail to protect the victim, for instance, trafficked victims are regarded as illegal immigrants. ${ }^{5}$

As such, this article seeks to examine briefly the legal framework within few receiving country members of ASEAN, where Malaysia becomes the main focus as "lesson learnt". The Malaysia main statute governing the matters related to human trafficking and migrant workers i.e. AntiTrafficking in Persons and Anti-Smuggling of Migrants Act 2007 is discussed. Then, few suggestions are highlighted based on the discussion made.

\section{Method}

The doctrinal research is adopted in this article which is mainly a library research.

\footnotetext{
4 Ramcharan, R. (2013). ASEAN's Problematic Intergovernmental Commission on Human Rights: The New Media's Role in Enhancing the Protection of Human Rights. Journal of International Studies. 9, 131 .

${ }^{5}$ Wuiling, C. (2006). Assessing criminal justice and human rights models in the fight against sex trafficking: A case study of the ASEAN region. Essex Human Rights Review, 3(1), 46-63.
} 
Primary data source from the legislation or statutes and reported cases. Meanwhile, secondary data is collected from journal articles, reports, books and online materials.

\section{Results and Analysis}

It is estimated that about 21.3 million ASEAN nationals live outside of their country to be migrants. Out of that number, approximately around 6.8 million individuals are migrants workers who move within ASEAN member countries and also known as intra-regional migrants. Myanmar is on the top of the list as source countries at 2.02 millions, followed by Indonesia (1.2 million), Malaysia (1.0 million), Lao PDR (0.9 million), and Cambodia (0.8 million). ${ }^{6}$ However, migrant workers suffer human right violations either by way of injustice treatment or human trafficking activities. Indonesia as one of the biggest source country of migrant workers within ASEAN, claims that out of 6.5 million Indonesian migrant workers working abroad (within ASEAN countries), about 1.5 million suffered human rights violations. ${ }^{7}$

As such, how do ASEAN goes about protection of migrant workers against human trafficking? In 1997, ASEAN agreed to a

\footnotetext{
6 ASEAN. (2017). ASEAN Compendium on Workers 'Education and Safe Migration Programmes. Jakarta: The Association of Southeast Asian Nations (ASEAN), p15.

7 Wicaksono, S. (2017). Improving ASEAN and its member countries role in migrant workers protection in ASEAN community. USU Journal of Legal Studies, 1(1), 107-130.
}

declaration namely ASEAN Declaration on Transnational Crime, which amongst others, pledges to 'expand the scope of Member Countries' efforts against transnational crime such as terrorism, illicit drug trafficking, arms smuggling, money laundering, traffic in persons and piracy. ${ }^{8}$ Later, in 2011, the ASEAN Ministerial Meeting on Transnational Crime agreed to explore the possibility of developing an ASEAN Convention on Trafficking in Persons. This is by way of strengthening regional cooperation, enhancing law-enforcement agencies, promoting a victim-centered approach, distinguishing victims of trafficking in persons from the perpetrators, and to ensure the victims are treated humanely and provides appropriate assistance to the victims. On top of that, it was agreed that an ASEAN Convention on Trafficking in Persons should be introduced. ${ }^{9}$

Later, ASEAN agreed to another declaration known as the ASEAN Declaration on the Protection and Promotion of the Rights of Migrant Workers. This Declaration was agreed on January $13^{\text {th, }} 2007$ in Cebu, Philippine. ${ }^{10}$ The general principles

8 ASEAN. (1997). ASEAN Declaration on Transnational Crime, 1997. Manila: ASEAN, paragraph 8.

ASEAN. (2017). ASEAN Document Series on Transnational Crime: Terrorism and Violent Extremism; Drugs; Cybercrime; and Trafficking in Persons. Jakarta: ASEAN, p4.

10 ASEAN. (2007). ASEAN Declaration on the Protection and Promotion of the Rights of Migrant Workers.

Online 
under Article 1 of the Declaration provides that member countries, either as the receiving states or sending states, shall promote freedom, equity, and stability of migrant workers in accordance with the national laws and policies of respective ASEAN Member Countries. Also the receiving and the sending have to take steps in ensuring the fundamental rights and dignity of migrant workers and their family members. ${ }^{11}$ The 2007 Declaration also emphasis in curbing the problem of human trafficking and provides that measure have to be taken to prevent the smuggling and trafficking in persons. $^{12}$

Then, on $21^{\text {st }}$ November 2015, the introduction of ASEAN Convention Against Trafficking in Persons Especially Women and Children was agreed by ASEAN member countries in Kuala Lumpur, Malaysia. ${ }^{13}$ The ASEAN Convention Against Trafficking in Persons, Especially Women and Children among others provides for criminalisation, ${ }^{14}$ prevention, ${ }^{15}$ protection $^{16}$ and repatriation and return of victims ${ }^{17}$ of trafficking in persons. The member countries of ASEAN that ratified the ASEAN Convention Against

https://www.ilo.org/dyn/migpractice/docs/117/Declara tion.pdf. Accessed 1/10/2018.

${ }^{11}$ Ibid, article 3.

${ }^{12}$ Ibid, article 17.

${ }^{13}$ Ibid, p15.

${ }^{14}$ ASEAN Convention Against Trafficking in Persons, Especially Women and Children 2015, article 5.

${ }^{15}$ Ibid, article 11.

${ }^{16}$ Ibid, article 14.

${ }^{17}$ Ibid, article 15 .
Trafficking in Persons, Especially Women and Children are Singapore (on January 25, 2016), Thailand (July 24, 2016), Vietnam (January 5, 2017), Myanmar (January 16, 2017), Philippines (February 6, 2017), Lao PDR (May 16, 2017), Malaysia (September 7, 2017) and Indonesia (November 27, 2017). However, Cambodia is yet to ratify the Convention. ${ }^{18}$ It is also interesting to note that among the 10 ASEAN Member States, only the Philippines has ratified the International Convention on the Protection of the Rights of All Migrant Workers and Members of Their Families. Cambodia and Indonesia have signed but not yet ratified it. It is an added significance to have an ASEAN instrument for the protection of the rights of migrant workers and members of their family. ${ }^{19}$ As far as the right of workers in Malaysia are concerned, there are various laws that address the protection of their rights, either for local or migrant workers such as Employment Act 1955, Industrial Relation Act 1967, Minimum Wages Consultative Council 2011 and Minimum Wages Order 2012 and 2013. ${ }^{20}$

It is worth to note that Malaysia is a

\footnotetext{
18 ASEAN. 2018. Instruments of Ratification. Online http://agreement.asean.org/agreement/detail/330.html accessed October 1, 2018.

19 Chalermpalanupap, T. (2008). Promoting and protecting human rights in ASEAN. The Nation, 18.

${ }^{20}$ Ayub, Z. A., Yusoff, Z. M., \& Wahab, H. A. \& Badarulzaman, M. H. (2016). Discrimination Against Migrant Workers in Malaysia. Mimbar HukumFakultas Hukum Universitas Gadjah Mada, 28(3), 556-568, p 561.
} 
signatory to the UN Convention on Elimination of Discrimination Against Women (CEDAW), the UN Convention on the Rights of the Child (CRC), and has ratified five of the eight core ILO Conventions. $^{21}$ While Malaysia has ratified the ASEAN Convention against Trafficking in Persons, Especially Women and Children, it is claimed that migrant workers from Indonesia suffers the plight of human trafficking and violations of human rights involving Malaysia. ${ }^{22}$ It is not the aim of this article to verify the truth of the incidents, but to highlight the legal measures that have been taken by Malaysia to overcome the problems of migrant workers and human trafficking.

\section{Malaysia Legal Initiatives on Migrant Workers and Human Trafficking}

Malaysia is a signatory to the ASEAN Declaration on Transnational Crime in 1997, the ASEAN Declaration on the Protection and Promotion of the Rights of Migrant Workers in 2007 and the ASEAN Convention Against Trafficking in Persons, Especially Women and Children. Being the signatories to the 1997 and 2007 Declarations, as well after the ratification of the 2015 Convention, Malaysia has taken few legal initiatives in complying the Declarations and the

\footnotetext{
${ }^{21}$ Robertson Jr, P. S. (2008). Migrant Workers in Malaysia-Issues, Concerns and Points for Action. Bangkok: Fair Labor Association.

${ }^{22}$ Wicaksono, S. (2017). Improving ASEAN and its member countries role in migrant workers protection in ASEAN community. USU Journal of Legal Studies, 1(1), 107-130, p109.
}

Convention, namely, the enactment of AntiTrafficking in Persons Act 2007 which came into force in 2008. Afterwards, the AntiTrafficking in Persons Act 2007 was amended in 2010 and currently known as Anti-Trafficking in Persons and AntiSmuggling of Migrants Act 2007 (ATIPSOM). ${ }^{23}$ With the amendment, ATIPSOM broadened the definition of trafficking to include all actions involved in acquiring or maintaining the labour or services of a person through coercion. ${ }^{24}$

ATIPSOM is an act that can be regarded as the most significant Malaysia's response to the ASEAN Declarations and Convention. The preamble of ATIPSOM provides that it is an Act to prevent and combat trafficking in persons and smuggling of migrants and other related matters. Now, we look into the provisions in the Act that reflect the ASEAN Declaration on the Protection and Promotion of the Rights of Migrant Workers in 2007 and the ASEAN Convention against Trafficking in Persons, Especially Women and Children.

The ATIPSOM defines "trafficking in persons" as "all actions involved in acquiring or maintaining the labour or services of a person through coercion, and includes the act of recruiting, conveying, transferring,

\footnotetext{
${ }^{23}$ Anti-Trafficking in Persons and Anti-Smuggling of Migrants Act 2007, section 1(1).

${ }^{24}$ ASEAN. (2017). ASEAN Compendium on Workers 'Education and Safe Migration Programmes. Jakarta: The Association of Southeast Asian Nations (ASEAN), p58.
} 
harbouring, providing or receiving a person for the purposes of this Act", while "smuggling of migrants" is defines as "arranging, facilitating or organizing, directly or indirectly, a person's unlawful entry into or through, or unlawful exit from, any country of which the person is not a citizen or permanent resident either knowing or having reason to believe that the person's entry or exit is unlawful; and recruiting, conveying, transferring, concealing, harbouring or providing any other assistance or service for the purpose of carrying out the acts of smuggling person referred to in the previous paragraph." 25

The ATIPSOM then further provides for the offence of trafficking in persons ${ }^{26}$ and aggravated offence of trafficking using threat, deception, abuse of power or force. ${ }^{27}$ The Act gives a special protection for children by providing special provision for the offence of trafficking in children. ${ }^{28}$

The ATIPSOM also criminalises the acts in relation to human trafficking, namely profiting from trafficked person, ${ }^{29}$ makes, obtains, gives, sells or "possesses fraudulent travel or identity document" for the purpose of facilitating an act of trafficking in persons ${ }^{30}$ and providing facilities in support ${ }^{31}$

\footnotetext{
${ }^{25}$ Anti-Trafficking in Persons and Anti-Smuggling of Migrants Act 2007, section 2.

${ }^{26}$ Ibid., section 12.

${ }^{27}$ Ibid., section 13 .

${ }^{28}$ Ibid., section 14

${ }^{29}$ Ibid., section 15 .

${ }^{30}$ Ibid., section 18 .
}

or services for the purposes of trafficking in persons. $^{32}$

Evidence-wise, to prove the mens rea of the human trafficking act, the ATIPSOM clearly states that the consent of trafficked person is irrelevant and is not a defence. ${ }^{33}$ Also, previous sexual behaviour, ${ }^{34}$ movement or conveyance of trafficked person is irrelevant. $^{35}$

Part IIIA of the Act is newly added by virtue of the 2010 amendment, governing the offence of smuggling of migrants. ${ }^{36}$ The preceding provisions under Part IIIA are governing the offences related to smuggling of migrants. Section 26B criminalises the aggravated offence of migrant smuggling, smuggling migrant in transit, ${ }^{37}$ profiting from smuggling activities, ${ }^{38}$ makes, obtains, gives, sells or "possesses fraudulent travel or identity document", ${ }^{39}$ providing facilities ${ }^{40}$ or services to smuggle migrant. ${ }^{41}$

Furthermore, Part V of ATIPSOM stipulates the care and protection of trafficked persons. It states clearly that Part V is not applicable to smuggled migrants unless the smuggled migrant is a trafficked person

\footnotetext{
${ }^{31}$ Ibid., section 20.

${ }^{32}$ Ibid., section 21.

${ }^{33}$ Ibid., section 16.

${ }^{34}$ Ibid., section 17.

${ }^{35}$ Ibid., section 17A.

${ }^{36}$ Ibid., section 26A.

${ }^{37}$ Ibid., section $26 \mathrm{C}$.

${ }^{38}$ Ibid., section 26D.

${ }^{39}$ Ibid., section 26E.

${ }^{40}$ Ibid., section $26 \mathrm{~F}$.

${ }^{41}$ Ibid., section $27 \mathrm{G}$.
} 
as defined by the Act. ${ }^{42}$ Section 42 of the Act empower the Minister to declare any places or building to be the place of refuge for the trafficked person, and the appointment of officers to take care the trafficked persons is provided under section 43. The trafficked persons who is under the custody at the refuge centre, may get the permission from the Minister to move freely or to work with certain conditions set out by the Minister. ${ }^{43}$ As provided under section 66 of ATIPSOM, the Minister may make orders or regulation to prescribe the qualifications, conditions, procedures or any other matters relating to the granting of permission to move freely and to work under section $51 \mathrm{~A} .{ }^{44}$ The welfare of the trafficked person further protected when the Act stipulates the power of the court to order payment of compensation to be paid by the convicted person. ${ }^{45}$ Besides, the payment of the compensation to the victim upon conviction of the offender shall not prevent any civil proceeding instituted by the victim. ${ }^{46}$ even in the case of acquittal of the accused, the court has the power to make an order for the payment of wages in arrears to the alleged trafficked person. ${ }^{47}$

Based on the discussion above, it is clear that Malaysia has put into place comprehensive legal framework to encounter

\footnotetext{
${ }^{42}$ Ibid., section $41 \mathrm{~A}$.

${ }^{43}$ Ibid., section $51 \mathrm{~A}$.

${ }^{44}$ Ibid., section 66(2)(aa).

${ }^{45}$ Ibid., section 66A(1).

${ }^{46}$ Ibid., section 66A(4).

${ }^{47}$ Ibid., section 66B(1).
}

the problems of migrant workers and human trafficking. Despite the legal measures taken by Malaysia, the authors will examine the "compliance" of the ATIPSOM with the ASEAN Convention Against Trafficking in Persons, Especially Women and Children that was introduced in 2015 and has been ratified by Malaysia in 2017. In general, all of the articles under the ASEAN Convention have been followed by Malaysia under ATIPSOM such as the definition of "trafficking in person" under Article 2(a) of the Convention, irrelevancy of victim's consent as defence, ${ }^{48}$ criminalisation of trafficking in persons and related activities as well as laundering the proceeds of the crimes. ${ }^{49}$

However, few areas maybe taken into account by Malaysia to enhance the protection for the victims of human trafficking and workers' smuggling, to be in conformity with the ASEAN Convention and Declarations. Firstly, on the inclusion of protection of the family of undocumented workers. It was asserted that Malaysia and Singapore played an active role to influence that families of migrant workers, are not included in the Declaration's coverage, ${ }^{50}$ even though it was later included under article 8 of the ASEAN Declaration on the Protection and Promotion of the Rights of

\footnotetext{
48 The ASEAN , article 2(b)

${ }^{49}$ Ibid., article 5, 6 and 7.

${ }^{50}$ Wicaksono, S. (2017). Improving ASEAN and its member countries role in migrant workers protection in ASEAN community. USU Journal of Legal Studies, 1(1), 107-130.
} 
Migrant Workers, ${ }^{51}$ the statute like ATIPSOM does not reflect the article's of the Declaration requirement. Secondly, on the implementation of ATIPSOM, it is claimed that the implementation of the law in relation to human trafficking and smuggling only focus primarily on cases of trafficking for sexual exploitation. ${ }^{52}$ Nevertheless, the former Attorney General of Malaysia states that the number of cases brought to court under ATIPSOM rose significantly with 253 cases up to Nov 24 in 2016 compared to 38 during the same period in 2015. the Attorney General also mentioned that from the 91 convictions, 71 cases involved human trafficking under Sections 12, 13, and 14 of the ATIPSOM. ${ }^{53}$ Thirdly, despite the fact that the victim may now get compensation as awarded by the court (e.g. under section $66 \mathrm{~A}(1)$ of ATIPSOM) upon conviction of the accused person, however, the payment o the compensation is ordered to the accused person. It is suggested that the ASEAN member countries to set up a fund to compensate the victim in case where the criminals are proven to have no money to compensate the victim.

Last but not least, a coherent transnational policy and laws on human

\footnotetext{
51 Robertson Jr, P. S. (2008). Migrant Workers in Malaysia-Issues, Concerns and Points for Action. Bangkok: Fair Labor Association.

${ }^{5}$ Ibid.

53 Bernama. (2016). 'Startling rise in human trafficking, migrant smuggling cases: AGC'. The Sun Daily. 28 November 2016. online at http://www.thesundaily.my/news/207675
}

trafficking and migrant workers should be enhanced amongst ASEAN countries. While Malaysia, Brunei Darussalam, Singapore and Thailand strengthening the law laws as receiving countries, it is noted that Indonesia, Philippine, Myanmar, Cambodia, Vietnam and Lao PDR are focusing their policy and laws as sending countries. For examples, in Thailand as receiving countries, introduced various laws on migrant workers and human trafficking, but one of the reason on the failure of the government in regularizing "irregular" migrant workers are due to the high costs and the complexity involved in the registration and work permit application process apart from the lack of law enforcement and lack of transparency. ${ }^{54}$ the policy in protecting migrant workers has not been a priority for Philippines and Indonesia at the regional level. ${ }^{55}$ As mentioned at the above, this is due to the fact that they are as sending countries rather than receiving countries. In Indonesia as one of the main sending countries in ASEAN, it is highlighted that the current national laws and policies mainly address the management of out-flowing of domestic workers abroad, reducing local unemployment and hence, less

\footnotetext{
54 Rukumnuaykit, P. (2009). A synthesis report on labour migration policies, management and immigration pressure in Thailand. Bangkok: ILO.

55 Santoso, A. (2012, March). Sociological Analysis on State Policy Behaviour in the Making of Regional Policy on the Protection of Migrant Workers: the Case of Indonesia and the Philippines in ASEAN. In Southeast Asian Studies Symposium (pp. 10-11).
} 
focus on protecting the migrants. ${ }^{56}$

\section{References}

Books with an author:

ASEAN. (2015). ASEAN Convention Against Trafficking in Persons, Especially Women and Children. Kuala Lumpur: ASEAN.

ASEAN. (1997). ASEAN Declaration on Transnational Crime, 1997. Manila: ASEAN.

ASEAN. (2017). ASEAN Compendium on Workers' Education and Safe Migration Programmes. Jakarta: The Association of Southeast Asian Nations (ASEAN).

ASEAN. (2017). ASEAN Document Series on Transnational Crime: Terrorism and Violent Extremism; Drugs; Cybercrime; and Trafficking in Persons. Jakarta: ASEAN.

Hangzo, P. K. K., Dumienski, Z., \& Cook, A. D. (2011). Legal Protection for Southeast Asian Migrant Domestic Workers: Why It Matters. NTS Insight, May, Singapore: RSIS Centre for NonTraditional Security (NTS) Studies.

Robertson Jr, P. S. (2008). Migrant Workers in Malaysia-Issues, Concerns and Points for Action. Bangkok: Fair Labor Association.

Rukumnuaykit, P. (2009). A synthesis report on labour migration policies, management and immigration pressure in Thailand. Bangkok: ILO.

\footnotetext{
${ }^{56}$ Hangzo, P. K. K., Dumienski, Z., \& Cook, A. D. (2011). Legal Protection for Southeast Asian Migrant Domestic Workers: Why It Matters. NTS Insight, May, Singapore: RSIS Centre for Non-Traditional Security (NTS) Studies.
}

\section{Journal articles:}

Chalermpalanupap, M. T. (1993). 10 Facts about ASEAN Human Rights Cooperation. World, 14, 25.

Chalermpalanupap, T. (2008). Promoting and protecting human rights in ASEAN. The Nation, 18

Chavez, J. J. (2007). Social policy in ASEAN: the prospects for integrating migrant labour rights and protection. Global Social Policy, 7(3), 358-378.

Ramcharan, R. (2013). ASEAN's Problematic Intergovernmental Commission on Human Rights: The New Media's Role in Enhancing the Protection of Human Rights. Journal of International Studies. 9, 1-31.

Santoso, A. (2012, March). Sociological Analysis on State Policy Behaviour in the Making of Regional Policy on the Protection of Migrant Workers: the Case of Indonesia and the Philippines in ASEAN. In Southeast Asian Studies Symposium (pp. 10-11)

Wicaksono, S. (2017). Improving ASEAN and its member countries role in migrant workers protection in ASEAN community. USU Journal of Legal Studies, 1(1), 107-130.

Wuiling, C. (2006). Assessing criminal justice and human rights models in the fight against sex trafficking: A case study of the ASEAN region. Essex Human Rights Review, 3(1), 46-63.

\section{World Wide Web:}

ASEAN. (2007). ASEAN Declaration on the Protection and Promotion of the Rights of Migrant Workers. https://www.ilo.org/dyn/migpractice/docs/ 117/Declaration.pdf. [accessed 1/10/2018]. 
ASEAN. (2018). Instruments of Ratification. http://agreement.asean.org/agreement/detai 1/330.html [accessed October 1, 2018].
Bernama. (2016). 'Startling rise in human trafficking, migrant smuggling cases: AGC'. The Sun Daily. 28 November 2016. http://www.thesundaily.my/news/207675. 